\title{
Study on the Environmental Barriers in International Trade
}

\author{
Ni Xing, Zhuoqing Zhang \\ Nanchang Institute of Science \& Technology, Nanchang, Jiangxi, 330000
}

Keywords: Environmental Barriers, International Trade, Green Trade Barriers

\begin{abstract}
In recent years, a new trend has emerged in world trade. Some developed countries have introduced a new trade protectionism by setting environmental quality standards higher than those of developing countries. That is, they adopt high standards of access as a means of restricting imports so that the traditional trade barriers gradually evolved into environmental barriers and became green trade barriers. With the increasingly stringent environmental protection standards in various countries, environmental barrier trade has increasingly become a form of new trade protectionism in international trade. Some traditional products manufactured, according to the old mode of production, have been restricted or even banned in international trade, which has affected the export trade in developing countries to a certain extent. Since the successful conclusion of the Uruguay Round negotiations in 1994 and the establishment of the WTO in 1995, the tariff barriers in international trade have been largely canceled and the traditional space for non-tariff barriers has been shrinking. However, as the global financial turmoil intensified, the world economic growth slowed down. The fierce competition in export trade and the intensification of the global trade imbalance caused the renovation of some countries and implemented "green" trade protectionism on the ground of environmental protection. In recent years, trade disputes caused by environmental barriers have become a major feature of international trade. For China, which joins the WTO, this trade barrier in the form of a legal outer garment has, and will continue to have a significant negative impact on the development of China's export enterprises and even the implementation of China's accession strategy. No matter from what point of view, "environmental barriers" will be the most difficult but must cross the threshold of China's foreign economic and trade activities. Therefore, it is necessary to have a full and objective understanding of green trade barriers, carefully study its basic content and characteristics, thoroughly grasp the law of its formation and development, and put forward feasible operational countermeasures in a timely manner [1].
\end{abstract}

\section{Introduction}

With the development of the world economy and the rise of the environmental protection wave in the world, sustainable development has become the consensus of the international community. The issue of trade and environment is increasingly gaining the attention of the international community, governments and people of all countries and has become one of the major issues in the international political and economic fields. Against this background, a measure that directly or indirectly limits or even prohibits trade on the grounds of protecting the life, health and safety of the people, animals and plants and protecting the ecological environment, the green trade barrier was born and replaced the tariff barriers and Traditional non-tariff barriers play an increasingly important role in international trade. Especially in recent years, the western developed countries such as the United States, Japan, the European Community and other major capitalist countries have adopted a concealed, less transparent and difficult to supervise and predict the protection measures environmental barriers, to our country and other countries, especially It is a great obstacle to the foreign trade of the developing countries and a barrier against the entry of foreign products into the domestic market. It is the most concealed and the most difficult trade barrier in today's international trade [2]. 


\section{Reasons for the negative impact of green trade barriers on China's foreign trade}

First, we use the method of partial equilibrium to analyze the effect of internalizing environmental costs. Figure 2-1 (a) shows the absence of external costs. Under such circumstances, without the intervention of the government, market forces can maximize social welfare. The marginal private cost ( $\mathrm{MPc}$ ) at this time is equal to the marginal private income (M) B. Among them, Is a balanced production, P. Is the market clearing price? As analyzed in the perfect competition model, assuming that a certain commodity is produced by a company with a monopoly power in the country and further assuming that the world market is completely competitive, the firm is the recipient of the international market price. When the world market price is lower than the domestic market price in a closed economy, the country will import commodities. Under such circumstances, the monopoly will not be able to monopolize the domestic market due to the lack of necessary trade barriers. Then the conditions under imperfect competition will be similar to the situation of complete competition analyzed earlier [3].

In general, the degree of internalization of environmental costs is inversely proportional to the comparative advantage of a country's products. In countries with full internalization of environmental costs, the comparative advantages of their products are small or have no comparative advantage; while in countries where environmental costs are not fully internalized, their products have comparative advantages. Therefore, the internalization of environmental costs in different countries will also change the comparative cost advantage of similar products in different countries, so that some countries lose their products with price competitiveness and exit the international market, while others enjoy price competitiveness to enter the international market.

As pollution control costs are often very high, some enterprises can not afford such expenses. In some underdeveloped countries in particular, it is even more difficult for polluting enterprises to solve the expensive pollution treatment costs themselves. Therefore, when implementing the internalization of environmental costs, the government often provides such enterprises with "pollution control subsidies." However, due to the different government subsidies provided by local governments to pollution control. As a result, the comparative advantages of the same products produced by similar enterprises in different countries will also change. Thus affecting their competitiveness in the international market.

\section{Green trade barriers of the complex mechanism}

Basically, the protection of environmental barriers against the domestic market forms a control mechanism for the prices of imported products and imported products, mainly from the customs territory. Therefore, the price control mechanism and the quantity control mechanism are the two most basic mechanisms. Once the environmental barriers are formed and implemented, the barriers have dual effects on the imported products with obvious quantitative control mechanism and price control mechanism. Its particularity is manifested in two aspects: First, it is connotative. It objectively requires that each party must pay the price of transforming the product to meet the requirements of the barrier. Under conditions of complete competition or monopolistic competition in the product market, there is a tendency for interest to enter the parties and they have to work hard to cross the barriers as quickly as possible. Otherwise it will lose market opportunities and market space, which is different from the role of tariffs. The second is externality. Before entering the market, imported goods must increase the price of imported goods in order to pass the examination of technical barriers, pay the inspection fees and the related or derivative costs, which is consistent with the role of tariffs. From a dynamic point of view, the imported products to cross barriers, it must be based on barriers specified requirements, improve product quality and improve the technical level. The improvement of the product often requires new investment, so that the improved product has a rather high cost, further weakening the comparative advantage of the product. Therefore, cross-border barriers are at the cost of rising costs of imports, which will affect the competitiveness of products for a period of time and reduce their sales profits. The dual 
compound regulation mechanism of the quantity and price of environmental barriers is not isolated but common to the imported products. At the same time, the main manifestation of this mechanism is variable at different periods when imported products enter [4].

\section{Countermeasures and suggestions}

Establishing an environment and trade policy that is both in line with international norms and in keeping with our own national conditions is an important task of the government in "environmental diplomacy." "Environmental diplomacy" was proposed by Japan in 1989 and originated from the situation where the environmental issue has increasingly become the focus of negotiations in international multilateral and bilateral negotiations. At present, "environmental diplomacy" has become the means for some countries, especially developed countries, to carry out international green marketing [5]. The diplomatic powers of developed countries have all taken the role of "chief salesmen" of their products in order to promote the development of their domestic environmental protection industry and the export of green products for our country, we should study the marketing approach of "environmental diplomacy." For a long time to come, the most widely used green trade barriers in developed countries will be technical regulations and technical standards. In the early 1980s, Britain, France, Germany and other countries to adopt international standards have reached $80 \%$, Japan's newly formulated national standards, more than $90 \%$ of the adoption of the International Organization for Standardization standards. At the same time, the overall level of technical barriers in our country lags behind that of developed countries in 20 to 30 years. It is far from being able to meet the requirements of adopting international standards and advanced foreign standards. Since the 1990s, our country has accelerated the adoption of international standards. Since 1997, the adoption rate of international standards has reached $60 \%$. However, as a whole, the status of our adoption of international standards is still lagging behind. Therefore, further steps should be taken to speed up the adoption of international standards.

The establishment of an early warning mechanism of green trade barriers is of great significance to the healthy development of China's foreign trade because the international standardization bodies and governments of all countries and their standardization bodies regularly revise their technical regulations and standards if the information of the enterprises is sluggish. Products that can not be produced in accordance with changed regulations or standards will encounter barriers when they are exported. Therefore, it is recommended that relevant government departments promptly set up an early warning mechanism for foreign green trade barriers so as to be responsible for the barrier information centers and databases. At the same time, we should carefully study the impact of green trade barriers on China's major export products, adopt proactive measures to deal with them and create a good export environment. In obtaining information on foreign green trade barriers, we should make full use of the national consultation points on technical standards and regulations provided by WTO Members under the "Agreement on Technical Barriers to Trade" and the "Agreement on the Implementation of Sanitary and Phytosanitary Measures." In addition, agencies such as the Counseling Service of Foreign Economic Relations and Trade can be utilized to collect timely information on foreign environmental technology barriers. Countries through the establishment of relevant information databases and websites to facilitate business inquiries, to provide enterprises with consulting services.

Faced with the global ecological crisis such as the deterioration of the global ecological environment and the shortage of natural resources, the international environmental conventions have been promulgated one after another. The environmental and technical standards in various countries are increasingly demanding the products and their production processes. The environmental laws and regulations are becoming more and more complicated and strict: many The concept of green consumption among consumers, especially in developed countries, has taken shape. There are indications that the real demand and potential demand for green consumption in the international market are great. The real market and the potential market for products that meet the environmental requirements are full of enterprises Allure of products that do not meet the environmental requirements will lose the international market, the production process does not meet 
environmental standards and regulations of enterprises will be discontinued. Many enterprises, especially internationalized large enterprises, have started to establish or have established the concept of international green marketing. Enterprises such as Qingdao Haier Co., Ltd., Guangdong Kelon Group Co., Ltd. and Henan Xinfei Electric Co., Ltd. set up the International Green Marketing concepts, proceed with the development of green appliances, certification is also very positive, foreign large enterprises, especially multinational corporations, the concept of international green marketing even more intense. Matsushita Electric Industrial Co., Ltd. requested Matsushita Group's 31 manufacturing enterprises in China to pass the 15014000 certification before the end of 1998; enterprises such as ABB Group and NEC required the enterprises in China to pass the 15014000 certification in the past two years. The EU also requires enterprises in China to pass 15014000 certifications before 2000 .

\section{Conclusions}

Environmental barriers have brought us tremendous impact and severe challenges. However, we should see that China's accession to the WTO has brought unprecedented opportunities for the development of the economy and foreign trade in our country. In the initial stage of accession to the WTO, how to adjust the relationship between challenges and opportunities and how to make better use of it while breaking environmental barriers so that our economy and trade can adapt to the international market as soon as possible has become a problem that China needs to solve urgently. The above is only the author put forward a few representative solutions to the problem. In short, in the early stage of China's accession to the WTO, we must find a suitable approach and countermeasure to our country's development as soon as possible, adjust our internal mechanism as soon as possible, work with the international community at an early date, effectively develop our foreign trade and environmental protection and gradually improve our country's Environmental protection and trade system.

\section{References}

[1] Wang Wenli, Wang Jiang. On the technical barriers to international trade of agricultural products countermeasures [J]. International Economic and Trade Exploration. 2003 (04):15 22.

[2] Jiang Bowing. Legal Reflections on WTO Green Barriers [J]. International Trade and Economic Exploration, 2003 (03) :162 166.

[3] Lin Jinzhong. On the Four Forms of Enterprise Scale Economy [J]. Economic Science. 2002 (06): :98 102.

[4] Li Shu. Green marketing to break the green barrier [J]. Business Times. 2002 (23) :33 35.

[5] Duan Qiong, Jiang Taiping. Effect of environmental standards on the competitiveness of international trade: an empirical analysis of China's industrial sector [J]. International Trade Issues, 2002 (12) :221 226. 